\title{
Alat Pendeteksi Kesegaran Daging Berdasarkan Sensor Bau dan Warna
}

\author{
Junaldi $^{1}$, Zulharbi ${ }^{2}$, Wiwin Lovita ${ }^{3}$ \\ ${ }^{123}$ Jurusan Teknik Elektro Politeknik Negeri Padang \\ junaldi@pnp.ac.id \\ Kampus Politeknik Negeri Padang, Limau Manis Padang
}

\begin{abstract}
In this study a system was designed to identify the level of freshness of the meat quickly and precisely. This system is implemented into Arduino uno, displayed via LCD as a result of identification and raises the sound of the buzzer as a sensor marker identified using odor sensors and color sensors as a freshness detection tool that replaces the sense of smell and vision in humans in determining the freshness of the meat. The input used is in the form of the voltage value of the odor sensor, namely the TGS2602 sensor along with the values of Red, Green and Blue obtained from the TCS3200 color sensor. There are 3 pieces of meat freshness tested, namely fresh meat, half-fresh meat and rotten meat. The use of odor sensors and color sensors in the system has managed to get a specific error and average for each level of freshness of the meat tested. From the results of testing of three samples representing the level of freshness of the meat. The freshness of the meat is determined through the time of storing meat outside the room at room temperature. the average stress on fresh meat is $<1,586$ volt, half-fresh meat is $>1,586$ volt $<1,86$ volt and rotten meat $<2,50$ volt. Errors occur in the identification of fresh and half-fresh meat that has a pattern that is not too different. However this meat is not suitable for consumption.
\end{abstract}

Keywords: Freshness of the meat, gas sensor (TGS 2602), color sensor (TCS3200), microcontroller, LCD, Buzzer

Abstrak - Pada penelitian ini dirancang sebuah sistem yang dapat mengidentifikasi tingkat kesegaran daging secara cepat dan presisi. Sistem ini diimplementasikan ke dalam Arduino uno, ditampilkan melalui LCD dari hasil identifikasi serta menimbulkan bunyi dari buzzer sebagai penanda sensor teridentifikasi dengan menggunakan sensor bau dan sensor warna sebagai alat pendeteksi kesegaran yang menggantikan indera penciuman dan penglihatan pada manusia dalam menentukan tingkat kesegaran daging. Input yang digunakan adalah berupa nilai tegangan dari sensor bau yaitu sensor TGS2602 beserta nilai Red, Green dan Blue yang didapatkan dari sensor warna TCS3200. Terdapat 3 buah kondisi kesegaran daging yang diuji yaitu daging segar, daging setengah segar dan daging busuk. Penggunaan sensor bau dan sensor warna pada sistem telah berhasil mendapatkan error dan rata-rata yang khusus untuk setiap tingkat kesegaran daging yang diuji. Dari hasil pengujian terhadap tiga buah sampel yang mewakili tingkat kesegaran daging. Tingkat kesegaran daging ditentukan melalui waktu penyimpanan daging diluar ruang pada suhu kamar. hasil rata-rata tegangan pada daging segar adalah $<1.586$ volt, daging setengah segar adalah $>1.586$ volt $<1.86$ volt dan daging busuk < 2.50volt. Error terjadi pada identifikasi daging segar dan setengah segar yang mempunyai pola yang tidak terlalu berbeda,. Bagaimanapun daging ini tidaklah layak untuk dikomsumsi.

Keyword: Kesegaran daging, sensor gas (TGS2602), sensor warna (TCS3200), microcontroller, LCD,Buzzer

\section{PENDAHULUAN}

Kesegaran daging merupakan faktor utama dalam menentukan kualitas dari sebuah daging. Tingkat kesegaran suatu daging akan menentukan apakah daging tersebut masih layak untuk dikonsumsi. Daging digunakan sebagai penganekaragaman sumber pangan karena daging dapat menimbulkan kepuasaan dan kenikmatan bagi yang memakannya. Kandungan gizi dari daging sangat lengkap sehingga keseimbangan gizi dapat terpenuhi. Salah satu daging yang banyak dikonsumsi oleh manusia adalah daging sapi. Saat ini tingginya kebutuhan daging dan terbatasnya ketersediaan daging dipasaran membuat harga daging menjadi mahal dan semakin banyak pedagang daging yang mencampurkan daging busuk kedalam daging segar. Untuk menghindari resiko masyarakat sebagai konsumen harus mewaspadai dan mengetahui karakteristik daging busuk dan perbedaannya dengan daging segar. Dalam hal tersebut meningkatnya keuntungan bagi pedagang daging nakal, namun sangat
(C) 2019 Elektron Jurnal Ilmiah merugikan masyarakat konsumen dan melanggar peraturan dan norma agama. Sayangnya masyarakat konsumen saat ini masih awam dan mengalami kesulitan dalam medeteksi daging segar atau busuk.

Berdasarkan permasalahan tersebut pada penelitian ini dikembangkan sebuah alat untuk Pendeteksi Kesegaran Daging Berdasarkan Sensor Bau dan Warna alat ini dapat mendeteksi kesegaran daging dengan memanfaatkan karakteristik dari pembusukan daging, digunakan sebuah sensor bau TGS2602 dan sensor warna TCS3200 untuk dapat mendeteksi tingkat kesegaran daging. Sensor bau berperan sebagai pendeteksi bau yang dikeluarkan oleh daging dan didapatkan data nilai tegangan. Kemudian sensor warna akan digunakan untuk mendeteksi perubahan nilai RGB dari warna daging. Beberapa penelitian yang terkait telah dilakukan, Nadya Ayu Nafiasaridan dkk[1] dalam penelitiannya menggunakan sensor warna TCS3200 sensor YL-96 merupakan sensor kelembaban untuk menganalisis kesegaran daging babi dengan parameter warna dan kelembaban. Saleh Dwiyatno 
dkk[2] melakukan penelitian yang sama tapi dengan objek yang berbeda yaitu pada ikan, menggunakan sensor warna sebagai alat pendeteksi kesegaran yang menggantikan indera penglihatan pada manusia dalam menentukan tingkat kesegaran ikan. Menggunakan metode K-Neirest Neighbor sebagai metode untuk melakukan pengenalan tingkat kesegaran ikan yang diuji. Input yang digunakan pada K-Neirest Neighbor adalah berupa nilai warna RGByang didapatkan dari sensor warna. Terdapat 3 buah kondisi kesegaran ikan yang diuji yaitu ikan segar, ikan cukupsegar dan ikan busuk. Tujuan dari penelitian ini adalah membuat suatu alat yang dapat mendeteksi kesegaran daging berdasarkan sensor warna TCS3200 dan sensor bau TGS2602.

\section{METODE PENELITIAN}

\subsection{Blok Diagram}

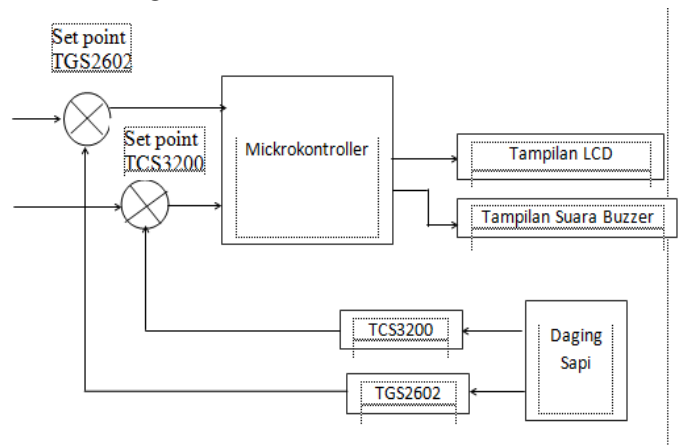

Gambar 1. Blok Diagram Sistem Kendali

Dari blok diagram diatas dapat dijelaskan prinsip kerja alat ini yaitu, daging sebagai sampel data diuji ke tempat pengujian alat, selanjutnya Sensor yang digunakan adalah sensor bau tipe TGS2602 dan sensor warna tipe TCS3200. Sensor bau digunakan untuk mengetahui nilai tegangan yang terkandung pada daging sedangkan sensor warna digunakan untuk mengidentifikasi warna daging yang menjadi deteksi dari kesegaran daging. Saat daging diuji dengan sensor bau maka didapatkan nilai tegangan yang nantinya nilai tegangan akan dikonversikan menjadi nilai bau pada arduino uno dan begitu pula dengan daging hasil identifikasi sensor warna membaca data RGB dari daging kemudian mengirim data yang didapat ke arduino uno untuk dapat diproses. Untuk nilai sensor bersifat analog dan dikonversikan pada arduino menjadi nilai data digital.

Semua informasi input dari sensor diproses oleh arduino uno dan akan ditampilkan ke LCD dan Buzzer sebagai monitoring dan penanda ketika sensor terbaca yang dipasang pada alat. Sebelumnya arduino uno diberi tegangan sebesar 9V dari power supply. Untuk mengetahui pembacaan pada sensor yang terukur, data tampilan pada LCD akan menampilkan hasil pengukuran dari sensor pada layar LCD dan Buzzer mengeluarkan bunyi sebagai tanda sensor terbaca.
2.2 Perancangan Hardware

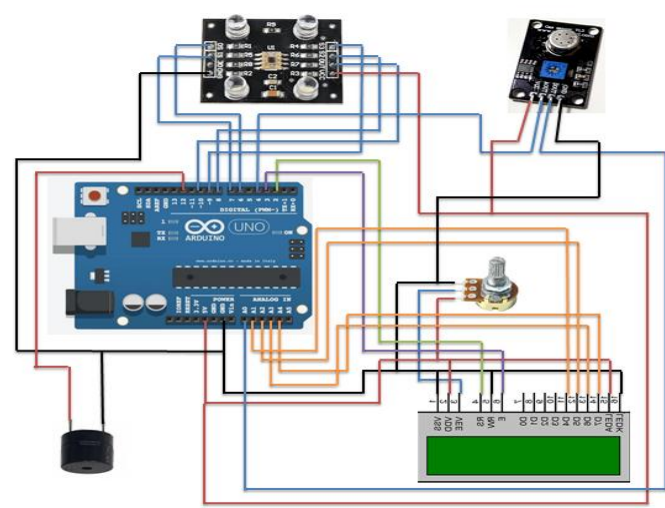

Gambar 2. Rangkaian Deteksi Kesegaran Daging

Sensor TGS2602 digunakan untuk membaca ADC Toluene dari senyawa VOC. Konfigurasi pin sensor ke mikrokontroler dapat dilihat pada tabel 1 .

Tabel 1. Konfigurasi Pin dari sensor TGS2602 ke mikrokontroler

\begin{tabular}{cc}
\hline $\begin{array}{c}\text { Pin Sensor } \\
\text { TGS2602 }\end{array}$ & $\begin{array}{c}\text { Terhubung Ke Arduino } \\
\text { Uno }\end{array}$ \\
\hline Vcc & Vcc $+5 \mathrm{~V}$ \\
\hline Aout & Pin A0 Arduino (analog) \\
\hline GND & Ground
\end{tabular}

Sensor TCS3200 digunakan untuk membaca nilai frekuensi yang didapatkan dari warna RGB sensor. Data digital ini akan menampilkan nilai RGB dari serial monitor microkontroler dan didapatkan range RGB untuk tingkat kesegaran dari daging tersebut.

Tabel 2. Konfigurasi Pin Digital Sensor TCS3200 ke mikrokontroler

\begin{tabular}{cc}
$\begin{array}{c}\text { Pin digital Sensor } \\
\text { TCS3200 }\end{array}$ & Terhubung Ke Arduino Uno \\
\hline Vcc & Vcc $+5 \mathrm{~V}$ \\
\hline GND & Ground \\
\hline S0 & Pin 6 \\
\hline S1 & Pin 7 \\
\hline S2 2 Pin 8 \\
\hline S3 & Pin 9 \\
\hline OUT & Pin 10 \\
\hline
\end{tabular}

Rangkaian LCD terhubung pada PinA1 - PinA4 pada mikrokontroler untuk data, sedangkan Pin3 dan Pin4 terhubung pada pin E dan RS pada LCD. Sedangkan rangkaian buzzer terhubung pada Pin12 (digital). 


\subsection{Perancangan Software}

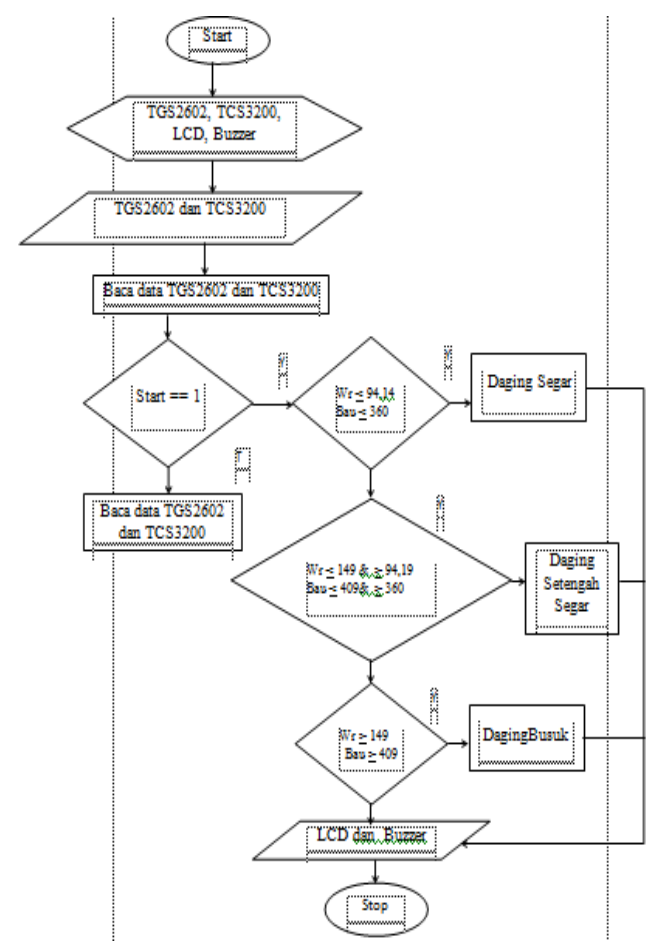

Gambar 3. Flowchart Sistem

Dari gambar 3 dapat dijelaskan, langkah awal melakukan inisialisasi pada sensor TGS dan TCS, selanjutnya sensor akan melakukan perbandingan, jika nilai sensor warna bernilai $<94,14$ dan sensor bau maka tampilan $\mathrm{LCD}=$ 'daging segar', jika nilai sensor warna $<149 \&>94,19$ dan sensor bau < 409\& > 360 maka tampilan pada $\mathrm{LCD}=$ 'daging setengah segar, jika nilai sensor warna > 149 dan sensor bau > 409 maka tampilan pada $\mathrm{LCD}=$ 'daging busuk'.

\section{HASIL DAN PEMBAHASAN}

Setelah pengerjaan seluruh sistem, maka perlu dilakukan pengujian dan penganalisaan terhadap alat yang dibuat. Pengujian dilakukan untuk mengetahui apakah alat yang dibuat dapat bekerja dengan baik sesuai dengan yang direncanakan atau tidak. Gambar 4 adalah bentuk alat yang telah dibuat.

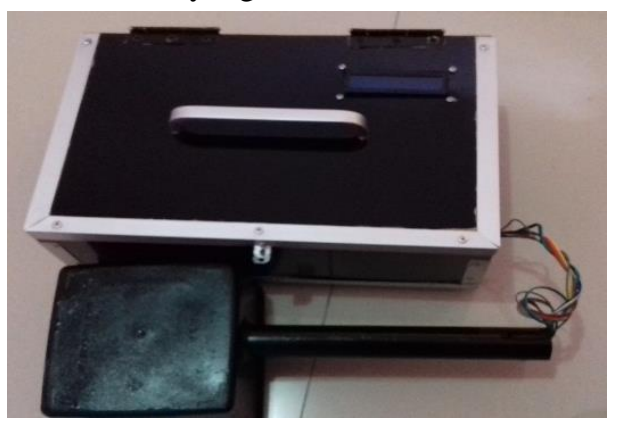

Gambar 4. Alat pendeteksi kesegaran daging sapi

\subsection{Pengujian Sensor Warna}

Pengujian sensor warna dilakukan untuk mengetahui apakah sensor ini dapat mengambil data berupa karakteristik warna suatu objek dengan benar dan akurat. Sensor TCS3200 akan mengeluarkan output berupa nilai RGB dari objek yang diarahkan pada daerah pendeteksiannya (array photodioda).

Tabel 3. Data Hasil Pengujian Sensor Warna pada Daging Segar

\begin{tabular}{cccc}
\hline Daging segar & Red & Green & Blue \\
\hline 1 jam & 50 & 125 & 100 \\
\hline 2 jam & 55 & 124 & 106 \\
\hline 3 jam & 52 & 131 & 107 \\
\hline 4 jam & 49 & 126 & 103 \\
\hline 5 jam & 56 & 134 & 108 \\
\hline 6 jam & 78 & 143 & 116 \\
\hline 7 jam & 84 & 150 & 121 \\
\hline Rata - rata & 60.57 & 133.29 & 108.71 \\
\hline
\end{tabular}

Tabel 4. Data Hasil Pengujian Sensor Warna pada Daging Setengah

\begin{tabular}{cccc}
\multicolumn{4}{c}{ Segar } \\
\hline $\begin{array}{c}\text { Daging Setengah } \\
\text { Segar }\end{array}$ & Red & Green & Blue \\
\hline 12 jam & 65 & 190 & 149 \\
\hline 13 jam & 71 & 197 & 156 \\
\hline 14 jam & 77 & 201 & 165 \\
\hline 15 jam & 79 & 204 & 166 \\
\hline 16 jam & 84 & 205 & 172 \\
\hline 17 jam & 85 & 209 & 174 \\
\hline 18 jam & 87 & 212 & 181 \\
\hline Rata - rata & 78.29 & 202.57 & 166.14
\end{tabular}

Tabel 5. Data Hasil Pengujian Sensor Warna pada Daging Busuk

\begin{tabular}{cccc}
\hline 24 jam & 102 & 150 & 120 \\
\hline 25 jam & 108 & 297 & 152 \\
\hline 26 jam & 114 & 214 & 169 \\
\hline 29 jam & 115 & 220 & 173 \\
\hline 30 jam & 108 & 210 & 179 \\
\hline \pm 2 hari & 120 & 222 & 180 \\
\hline \pm 2 hari & 124 & 227 & 189 \\
\hline Rata-rata & 113 & 214 & 171.42 \\
\hline 24 jam & 102 & 150 & 120 \\
\hline
\end{tabular}

Dari tabel 1 didapatkan nilai rata-rata RGB dari daging segar segar terlihat tidak jauh berbeda dari mulai 1 jam sampai 7 jam pengujian. Perubahan daging segar tersebut seiring dengan terjadinya proses pembusukan. Warna daging segar yang umumnya ditemukan di pasaran adalah berwarna merah cerah. Daging yang kurang segar akan memiliki warna merah yang agak gelap.

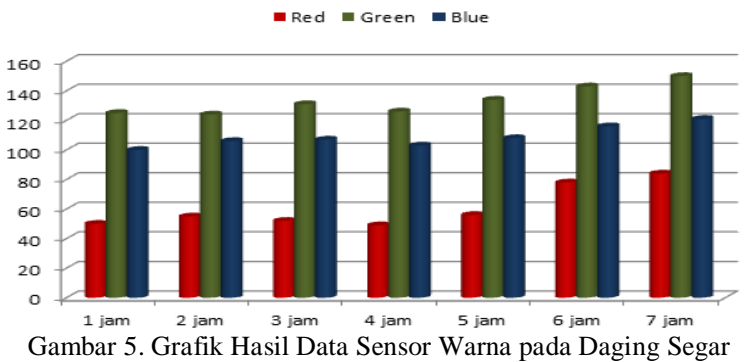


Pada hasil data pengujian sensor warna terhadap daging segar didapatkan data nilai RGB dengan hasil R lebih kecil nilai frekuensinya dibandingkan dengan $\mathrm{G}$ dan $\mathrm{B}$ dan didapatkan nilai rata-rata $\mathrm{R}$ adalah 60.57 , $\mathrm{G}$ adalah 133.29 dan B adalah 108.71 sesuai dengan dengan hasil grafik yang didapat pada gambar 5. Daging segar ini diambil data pengujian pada pukul 09.00 WIB hingga 16.00 WIB sore hari, pada suhu kamar pada perubahan gambar daging segar tidak teralu mengalami perubahan yang terlalu berbeda. Dari tabel 4 didapatkan nilai ratarata RGB dari daging setengah segar dan gambar dari daging segar terlihat tidak jauh berbeda dari mulai 12 jam sampai 18 jam pengujian.

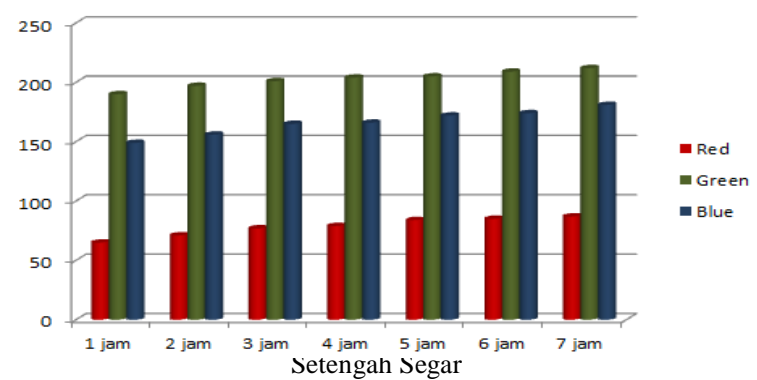

Pada hasil data pengujian daging setengah segar ini didapatkan hasil RGB dan grafik bembanding tidak jauh berbeda dengan hasil RGB pada daging segar. Nilai frekuensi dari $G$ lebih besar dibandingkan nilai frekuensi $\mathrm{R}$ dan $\mathrm{B}$. didapatkan nilai rata-rata $\mathrm{R}$ adalah 78.29, untuk G adalah 202.57 dan B adalah 166.14 sesuai dengan grafik nilai data sensor pada gambar 6 . Daging setengah segar ini diambil data pengujian pada pukul 04.00 WIB hingga 11.00 WIB pagi hari, pada suhu kamar. pada perubahan gambar daging setengah segar terlihat perubahan dari daging segar. Daging setengah segar terlihat pucat akibat pengaruh suhu kamar selama +18 jam. Dari tabel 5 didapatkan nilai rata-rata RGB dari daging setengah segar segar dan gambar dari daging segar terlihat tidak jauh berbeda dari mulai 24 jam sampai +2 hari pengujian.

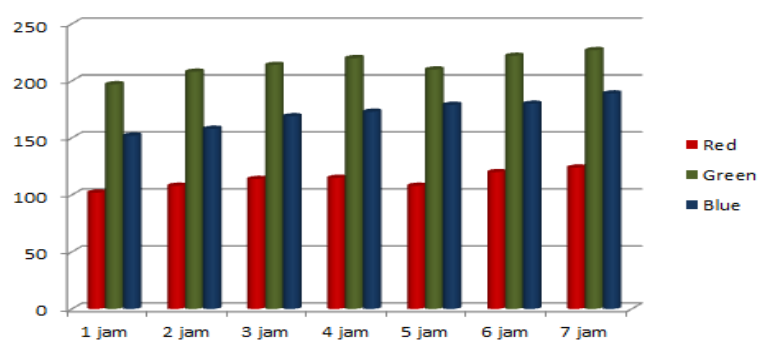

Gambar 7. Grafik Hasil Data Sensor Warna pada Daging Busuk

pada hasil data pengujian daging busuk nilai RGB meningkat dari nilai data daging segar dan setengah segar. Nilai frekuensi yang didapat rata-rata untuk nilai $\mathrm{R}$ adalah 113, untuk nilai $\mathrm{G}$ adalah 214 dan untuk nilai B adalah 171.42 sesui dengan hasil grafik nilai data sensor warna pada gambar 7 .
Daging busuk ini diambil data pengujian pada pukul 11.00 WIB malam hingga 06.00 WIB pagi hari, pada suhu kamar. Pada perubahan gambar daging busuk terlihat perubahan dari daging segar dan setengah segar. Daging busuk terlihat hitam dan membusuk serta berjamur akibat pengaruh suhu kamar selama +2 hari.

\subsubsection{Analisa Pengujian Sensor Warna}

Dari data yang didapatkan, diperoleh suatu pola dan hubungan antara tingkat kesegaran daging terhadap karakteristik warnanya. Daging segar memiliki nilai RGB terendah dibandingkan dengan dua buah sampel daging lainnya. Sesuai dengan gambar 30 didapatkan perbandingan dari daging segar, setengah segar dan daging busuk. Nilai data warna maka akan terlihat jelas perbedaan tingkat RGB dari warna daging.

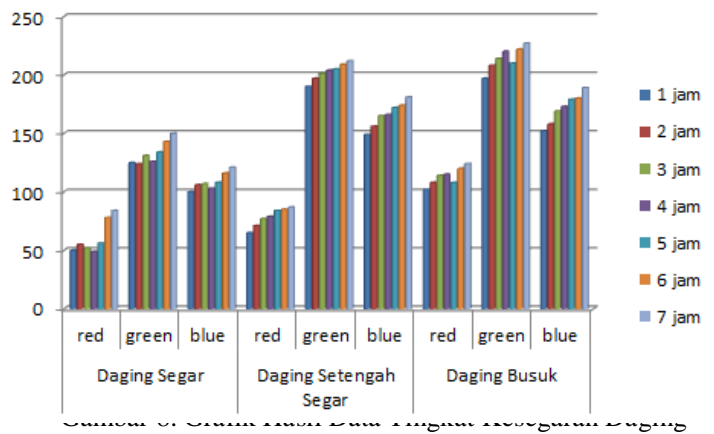

Sensor warna yang dipasang memiliki nilai resistansi yang berubah-ubah bila mendeteksi warna yang berbeda. Output dari sensor warna ini berupa frekuensi yang dipengaruhi oleh warna yang dideteksi, pengaruh cahaya dari luar dan jarak antara sensor dengan warna yang akan dideteksi memberikan pengaruh tingkat presisi data pembacaan sensor, maka dalam penggunaannya sensor berada dalam lingkungan yang gelap untuk mendapatkan hasil maksimal dalam pembacaan warna. Sesuai dengan datasheet, jarak optimal pembacaan sensor dengan objek didepannya yaitu 2,5 cm dari circuit board sensor. Area pembacaan sensor sendiri memiliki daya pandang $3,5 \times 3,5 \mathrm{~mm}$. Sensor bekerja secara berurutan dimulai dari filter photodiode red, lalu filter photodiode green, dan terakhir filter photodiode blue. Proses pertama dimulai dari photodiode red menangkap cahaya pantulan led yang mengenai daging berupa arus dan diubah oleh oscillator menjadi sinyal kotak yang mana besar frekuensinya ditentukan oleh besarnya intensitas cahaya yang ditangkap photodiode red. Proses selanjutnya untuk filter green dan blue sama seperti filter red. Dari hasil frekuensi yang didaptkan red, green, dan blue didaptkan range pembacaan ketika daging segar, setengah segar dan daging busuk. Untuk range pembacaan sensor warna pada microcontroller adalah sebagai berikut: 
1. Daging segar if $(R<85 \& R>50 \& G<150$ \& $\mathrm{G}>130 \& \mathrm{~B}<125 \& \mathrm{~B}>100)$

2. Daging setengah segar if $(R<100 \& R>65 \&$ $\mathrm{G}<200$ \& $\mathrm{G}>150$ \& $\mathrm{B}<185 \& \mathrm{~B}>145)$

3. Daging busuk if $(R<150 \& R>100 \& G<230 \&$ $\mathrm{G}>150 \& \mathrm{~B}<190 \& \mathrm{~B}>120$

Pembacaan frekuensi tingkat kesegaran daging akan ditampilkan pada LCD sesuai dengan urutan dasar warna daging tersebut, yaitu red, green, dan blue secara berurutan dan buzzer akn berbunyi. Lalu hasil data yang telah diperoleh akan di analisis oleh mikrokontroler dengan cara menyusun range dan batasan RGB tiap - tiap pembacaan daging yang dimasukkan ke alat.

\subsection{Pengujian Sensor Bau}

Pengujian sensor bau dengan tipe TGS2602 dilakukan dengan tujuan untuk mengetahui bagaimana sensor ini akan merespon terhadap perubahan tingkat kesegaran yang terjadi pada daging. Untuk menguji respon sensor bau terhadap sampel daging yang diuji diterapkan beberapa aturan yang akan secara konsisten dilakukan dalam setiap pengujian sebagai berikut :

1. Ruang uji adalah sebuah kubus berukuran 15 $\mathrm{cm} \times 15 \mathrm{~cm} \times 15 \mathrm{~cm}$ yang tertutup rapat dimana di dalamnya terdapat modul sensor gas. Sensor bau berada di bagian atas dari ruang uji dan sampel daging berada di bawah saat pengujian berlangsung.

2. Pengambilan data tegangan sensor gas berlangsung selama 30 detik mulai dari saat daging memasuki ruang uji sensor.

3. Pengujian sensor bau terhadap sampel daging dimulai dengan sampel berupa daging segar. Proses pengambilan data dilakukan dengan mengikuti aturan pengambilan data.

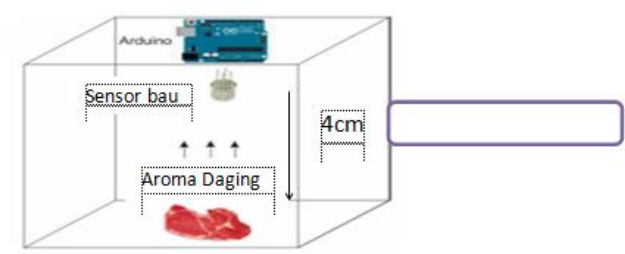

Gambar 9. Gambar Pengujian Ruang Sensor Bau

Tabel 6. Pengujian Tegangan Sensor Bau pada Daging Segar, setengah segar dan daging busuk

\begin{tabular}{|c|c|c|c|c|}
\hline $\begin{array}{c}\text { Tingkat } \\
\text { Kesegaran } \\
\text { Daging }\end{array}$ & Waktu & $\begin{array}{l}\text { Nilai } \\
\text { ADC }\end{array}$ & $\begin{array}{l}\text { Pengukuran } \\
\text { Tegangan } \\
\text { Output (volt) }\end{array}$ & $\begin{array}{l}\text { Rata-rata nilai } \\
\text { ADC dan } \\
\text { Tegangan } \\
\text { Output (volt) } \\
\end{array}$ \\
\hline \multirow{3}{*}{$\begin{array}{l}\text { Daging } \\
\text { Segar }\end{array}$} & $1 \mathrm{jam}$ & 291 & 1.40 & \multirow{3}{*}{$\begin{array}{l}\mathrm{Adc}=327.43 \\
\text { Vout }=1.586\end{array}$} \\
\hline & $2 \mathrm{jam}$ & 306 & 1.48 & \\
\hline & $3 \mathrm{jam}$ & 313 & 1.52 & \\
\hline
\end{tabular}

\begin{tabular}{|c|c|c|c|c|}
\hline & 4 jam & 328 & 1.59 & \\
\hline & $5 \mathrm{jam}$ & 340 & 1.65 & \\
\hline & $6 \mathrm{jam}$ & 354 & 1.72 & \\
\hline & $7 \mathrm{jam}$ & 360 & 1.74 & \\
\hline \multirow{7}{*}{$\begin{array}{c}\text { Daging } \\
\text { Setengah } \\
\text { Segar }\end{array}$} & $12 \mathrm{jam}$ & 360 & 1.73 & \multirow{7}{*}{$\begin{array}{c}\mathrm{Adc} \\
\text { Vout }=385.71 \\
=1.86\end{array}$} \\
\hline & $13 \mathrm{jam}$ & 371 & 1.78 & \\
\hline & $14 \mathrm{jam}$ & 376 & 1.80 & \\
\hline & $15 \mathrm{jam}$ & 383 & 1.86 & \\
\hline & $16 \mathrm{jam}$ & 395 & 1.91 & \\
\hline & 17 jam & 406 & 1.96 & \\
\hline & $18 \mathrm{jam}$ & 409 & 1.98 & \\
\hline \multirow{7}{*}{$\begin{array}{l}\text { Daging } \\
\text { Busuk }\end{array}$} & $24 \mathrm{jam}$ & 498 & 2.40 & \multirow{7}{*}{$\begin{array}{l}\mathrm{Adc}=517 \\
\text { Vout }=2.50\end{array}$} \\
\hline & $25 \mathrm{jam}$ & 502 & 2.42 & \\
\hline & $26 \mathrm{jam}$ & 516 & 2.49 & \\
\hline & $29 \mathrm{jam}$ & 518 & 2.50 & \\
\hline & $30 \mathrm{jam}$ & 520 & 2.53 & \\
\hline & $\begin{array}{l} \pm 2 \\
\text { hari }\end{array}$ & 527 & 2.54 & \\
\hline & $\begin{array}{l} \pm 2 \\
\text { hari }\end{array}$ & 538 & 2.59 & \\
\hline
\end{tabular}

Ketika data ADC yang diterima oleh sensor adalah 498 pada daging busuk, didapat tegangan yang diukur adalah 2.40 volt. Untuk tegangan 2.40 volt didapat perhitungan data ADC menggunakan rumus:

$$
\begin{aligned}
a d c & =\text { Vin: Vref } / 1023 \\
& =2.40: \frac{5}{1023} \\
& =\frac{2.40}{0.0048}=500
\end{aligned}
$$

Ketika data ADC 500 dapat dihitung kadar kandungan bau yang dideteksi oleh sensor adalah Perhitungan kadar bau $(\mathrm{ppm})=0.029296875 \times 500=14.64 \mathrm{ppm}$. Berarti sensor akan mengaktifakan output ketika bau yang dideteksi oleh sensor adalah dengan kadar 14.64ppm. Untuk mengetahui kadar bau berdasarkan data ADC, dapat dihitung dengan rumus:

$$
P P M=X x \text { Konversi adc }
$$

Dimana $X=0.029296875$, dan Konversi adc $=$ Nilai ADC pada sensor

Ketika nilai ADC yang ditampilkan semakin kecil, maka kadar bau yang dideteksi sensor juga akan semakin rendah. Nilai ADC berbanding lurus dengan kadar gas yang dideteksi oleh sensor. Untuk mencari nilai X melalui data sheet dari TGS 2602. 
Sensor TGS2602 mempunyai range deteksi antara 1 10 ppm, Range $=30-1=29$, Total Bit $=1024$.

$$
\begin{gathered}
X=\frac{\text { Range }}{\text { Total bit }} \\
=29 / 1024 \\
X=0.029296875
\end{gathered}
$$

Pada Saat Data ADC bau $=1.40$ volt (level deteksi minimum) dapat dihitung kadar bau dalam PPM adalah sebagai berikut :

Untuk 1.40 didapat data ADC adalah 291

$$
\begin{gathered}
P P M=X \times \text { Konversi adc } \\
=0.029296875 \times 291 \\
=8.53 \mathrm{ppm}
\end{gathered}
$$

Jadi level deteksi minimum bau yang dideksi oleh sensor adalah $8.53 \mathrm{ppm}$. Konsentrasi bau dengan kadar $8.53 \mathrm{ppm}$ dengan tegangan 1.40 volt adalah berbanding lurus, jika tegangan yang dihasilkan semakin besar, berarti kadar bau yang dideteksi juga akan semakin tinggi.

\subsection{Pengujian Alat pada Pedagang Daging Sapi}

Setelah dilakukan pengujian terhadap masingmasing sensor, selanjutnya dilakukan pengujian alat kepada tiga pedagang sapi

Tabel 7. Hasil Deteksi Daging Sapi yang dijual Pedagang Sapi 1

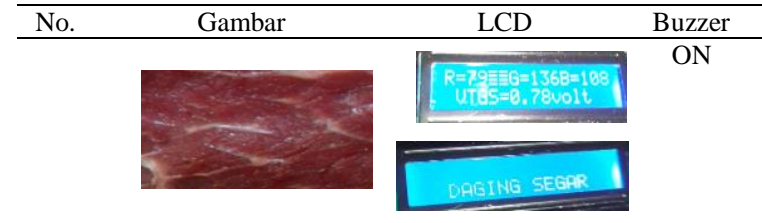

Daging yang dijual oleh Pedagang Sapi 1 ini adalah daging segar dengan tingkat kesegaran adalah daging

\begin{tabular}{|c|c|c|c|}
\hline No. & Gambar & LCD & Buzzer \\
\hline & & & $\mathrm{ON}$ \\
\hline
\end{tabular}
segar, yakni daging yang baru disembelih atau kurang dari 6-7 jam setelah penyembelihan. RGB yang didapatkan adalah $\mathrm{R}=79, \mathrm{G}=136$ dan $\mathrm{B}=108$, tegangan VTGS $=0.78$ volt dengan $\mathrm{ADC}<1$ volt .

Tabel 8. Hasil Deteksi Daging Sapi yang dijual Pedagang Sapi 2

Daging yang dijual oleh Pedagang Sapi 2 ini adalah daging segar dengan tingkat kesegaran adalah daging segar, yakni daging yang baru disembelih atau kurang dari 6-7 jam setelah penyembelihan. RGB yang didapatkan adalah $\mathrm{R}=71, \mathrm{G}=138$ dan $\mathrm{B}=111$, tegangan VTGS $=1.49$ volt dengan $\mathrm{ADC}=306$.
Tabel 9. Hasil Deteksi Daging Sapi yang dijual Pedagang Sapi 3

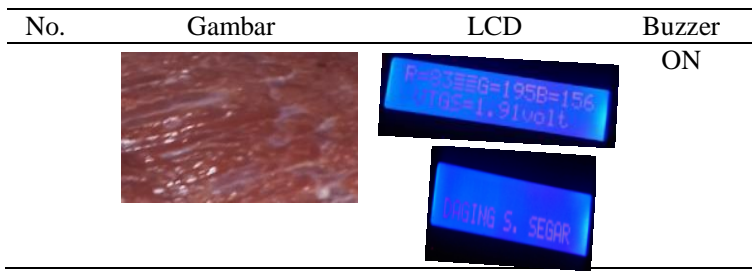

Daging yang dijual oleh Pedagang Sapi 3 ini adalah daging setengah segar dengan tingkat kesegaran adalah daging setengah segar, yakni daging yang sudah +12 jam setelah penyembelihan. RGB yang didapatkan adalah $\mathrm{R}=83, \mathrm{G}=195$ dan $\mathrm{B}=156$, tegangan VTGS $=1.91$ volt dengan $\mathrm{ADC}=395$. Untuk daging yang dijual pak kohar ini daging pada jam ke 5 pada tabel dari tingkat kesegaran daging setengah segar setelah + 12 jam.

\section{KESIMPULAN}

Setelah melakukan perancangan, pembuatan, serta pengujian alat pendeteksi kesegaran daging berdasarkan sensor bau dan warna dapat diambil kesimpulan sebagai berikut:

1. Tingkat kesegaran daging ditentukan melalui waktu penyimpanan daging di luar ruangan pada suhu kamar. Hasil rata-rata tegangan pada bau daging segar adalah < 1.586volt, daging setengah segar adalah > 1.586volt < 1.86 volt dan daging busuk $<2.50$ volt. Hasil rata-rata frekuensi untuk nilai sensor warna adalah

a. Daging segar, $60.57(\mathrm{R}), 133.29(\mathrm{G})$, dan $108,71(\mathrm{~B})$.

b. Daging setengah segar, $78.29(\mathrm{R})$, 202.57 (G) dan 166.14 (B).

c. Daging busuk, $113(\mathrm{R}), 214(\mathrm{G})$ dan $171.43(\mathrm{~B})$.

2. Nilai ADC yang ditampilkan semakin kecil, maka kadar bau yang dideteksi sensor juga akan semakin rendah. Nilai ADC berbanding lurus dengan kadar gas yang dideteksi oleh sensor.

\section{REFERENSI}

[1] Nadya Ayu Nafiasaridan Ariesta, Martiningtyas Handayani. Penganalisis Kesegaran Daging Sapi Dan Daging Babi Mentah Berdasarkan Klasifikasi Warna Dan Kelembaban. JURNAL TEKNOSAINS VOL 8, NO.1, Desember 2018; 66-76.

[2] Saleh Dwiyatno, Iksal, Sandi Nugraha. Alat Pendeteksi Kesegaran Ikan Menggunakan Metodek-Nearest Neighbor Berdasar Warna Mata Berbasis Atmega 328. Jurnal PROSISKO Vol. 5 No. 2 September 2018, hal: 127-135

[3] Dimas Rizki Radityo; Muhammad Riyan Fadillah; Quincy Igwahyudi; Satrio Dewanto. Alat Penyortir Dan Pengecekan Kematangan Buah Menggunakan Sensor Warna. Jurnal Teknik Komputer Vol. 20 No.2 Agustus 2012: 88-92. 
[4] Priyadi. Aplikasi Sensor Warna Jenis TCS230 Sebagai Alat

Vol.7 no. (2)

Penentu Komposisi Warna Pada Cat Mobil. Jurnal Eltek Vol. 10 No.

(2)

[5] Mandari, Y. dan Pangaribowo, T. (2016). "Rancang Bangun Sistem Robot Penyortir Benda Padat Berdasarkan Warna Berbasis Arduino”. Jurnal Teknologi Elektro Universitas Mercu Buana 